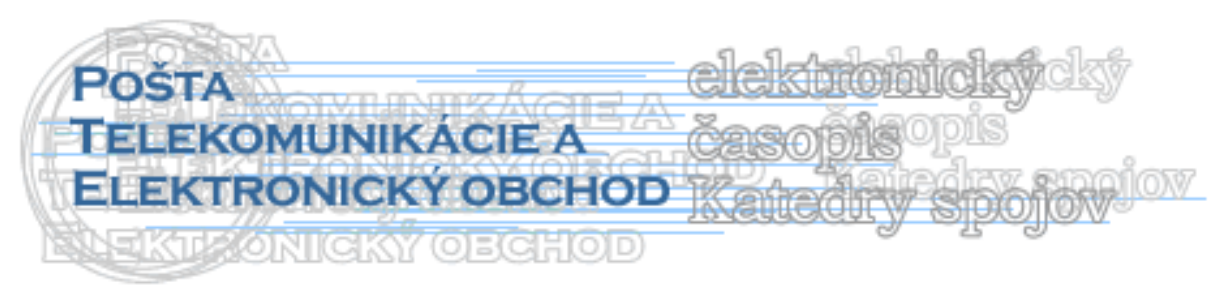

\title{
E-SOLUTIONS RESEARCH IN PROCUREMENT AREA
}

\author{
Jana Majchráková ${ }^{1}$, Iveta Kremeňová ${ }^{2}$
}

\begin{abstract}
This articel shares results from research done in electronic procurement area. It was conducted with the main aim of provision of transparent overview about available providers and their IT solutions. The outcome should serve not only scientific purposes but represents also important information for business sector which can benefit greatly of it.
\end{abstract}

Keywords: electronic procurement, digitalization, digital platforms

\section{Digitalization of procurement processes}

Digitization of procurement area is currently receiving great attention, both in the Slovak Republic as well as abroad. Rapid technological progress, the development of information systems in all areas of society and the way they are applied are among the main factors leading to the need for innovation and digitization in this field. It is becoming a necessary precondition for maintaining one's own competitiveness. In the future, value-added processes will continue to gain on the digitization level and will gradually automatically cover all sectors. The digital platforms that will be deployed will transform future value creation.

\section{Status and outlook of electronic procurement}

According to one of the latest studies in procurement area, the perceived need of companies to use electronic tools in the field of purchasing ranges from $69.1 \%$ to $90.6 \%$, depending on the sub-area of the application within procurement processes. The study includes following applications, or better said categories of electronic tools:

- Plan-to-Strategy

- Source-to-Contract

- Requisition-to-Pay (R2P) / Procure-to-Pay2

- Category-specific Tools

- Supplier Relationship Management (SRM)

- Quality Management (QM)

- Spend Analysis / Controlling

\footnotetext{
${ }^{1}$ Ing. Jana Majchráková, SIEMENS AG, Freyeslebenstr. 1, 91058 Erlangen, Nemecko, tel.: +49 152 54765381, e-mail: jana.majchrakova@siemens.com

${ }^{2}$ doc. Ing. Iveta Kremeňová, PhD., Žilinská Univerzita v Žiline, Fakulta prevádzky a ekonomiky dopravy a spojov, Katedra spojov, Univerzitná 8215/1, 01026 Žilina, SR, tel: +421911 170970 , e-mail: iveta.kremenova@fpedas.uniza.sk
} 


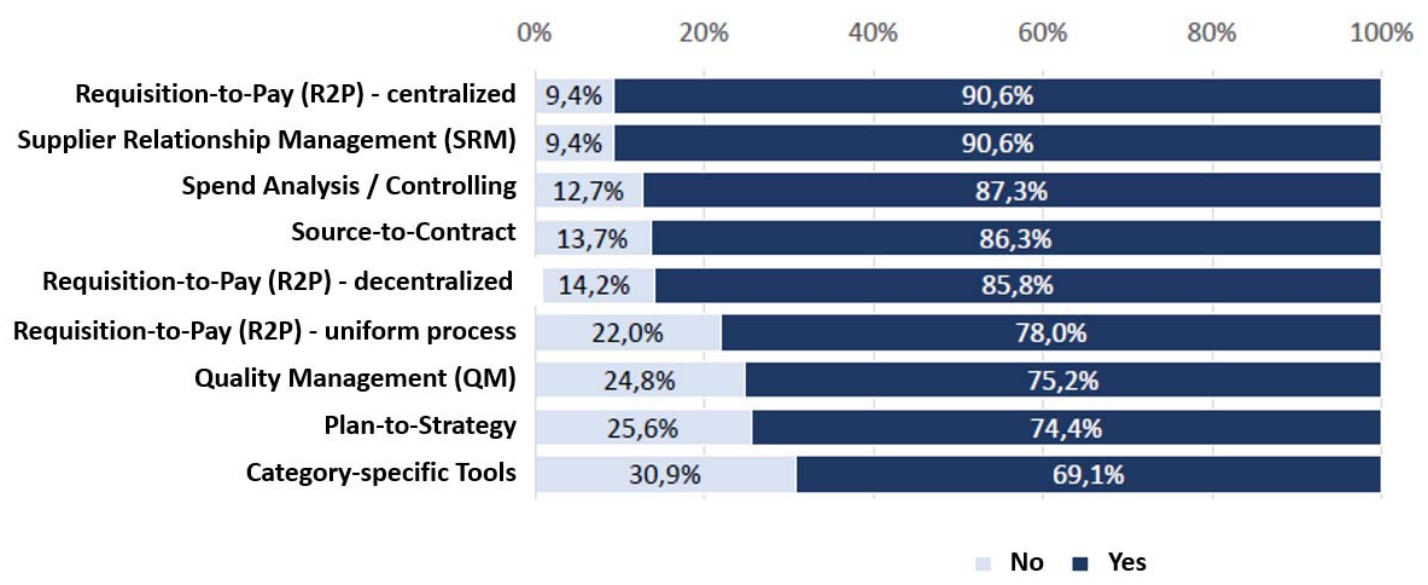

Figure 1 Perceived need of companies to use electronic tools (Source: ELEKTRONISCHE BESCHAFFUNG 2020 [1])

Despite research results showing a high level of perceived need for electronic tools in procurement area by companies, the survey points show a relatively low "average intensity of electronic tool use" in defined areas. Only $10.6 \%-37.1 \%$ fall into the category of a complete digitized solution. The data clearly indicate the potential for digitization of procurement processes. This fact is further confirmed by other findings of the research conducted in the category "Average target intensity of use of electronic tools". This represents the effort of companies to achieve an exclusively electronic solution for individual purchasing processes in the range of $18.1 \%-59.3 \%$.

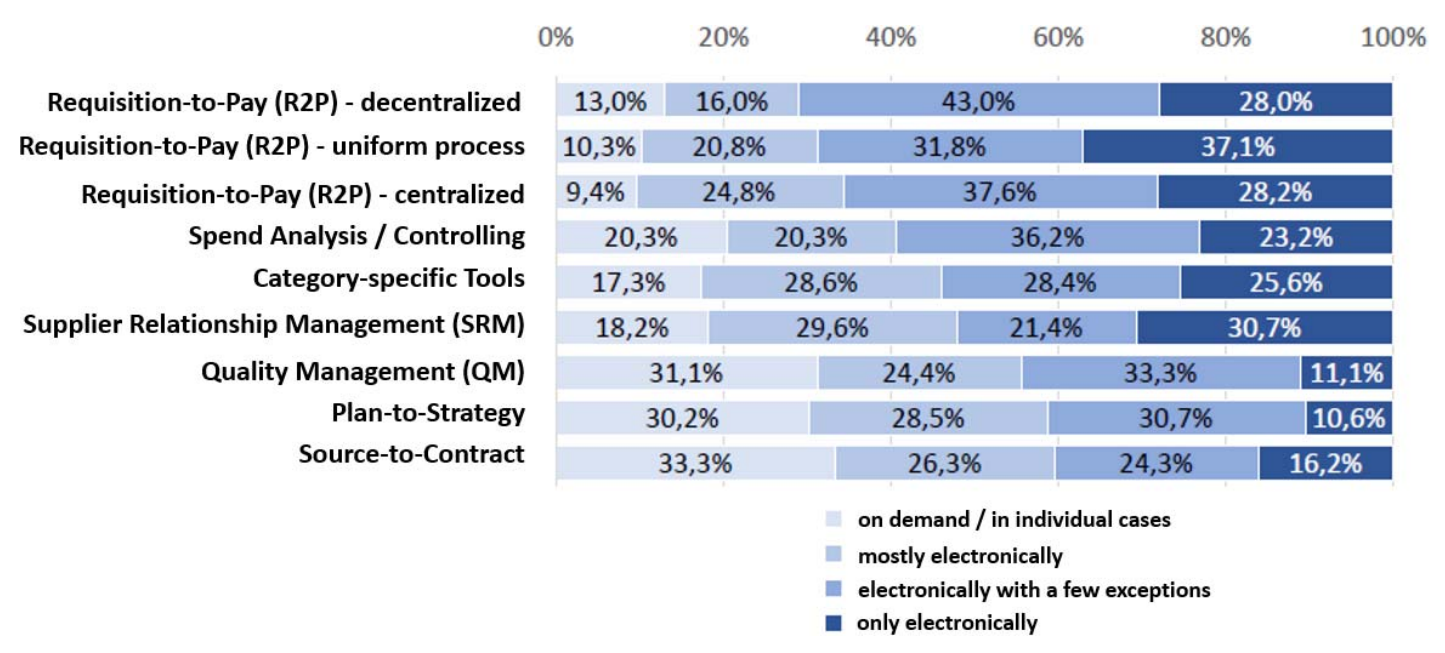

Figure 2 Average intensity of use of electronic tools (Source: ELEKTRONISCHE BESCHAFFUNG 2020 [1]) 


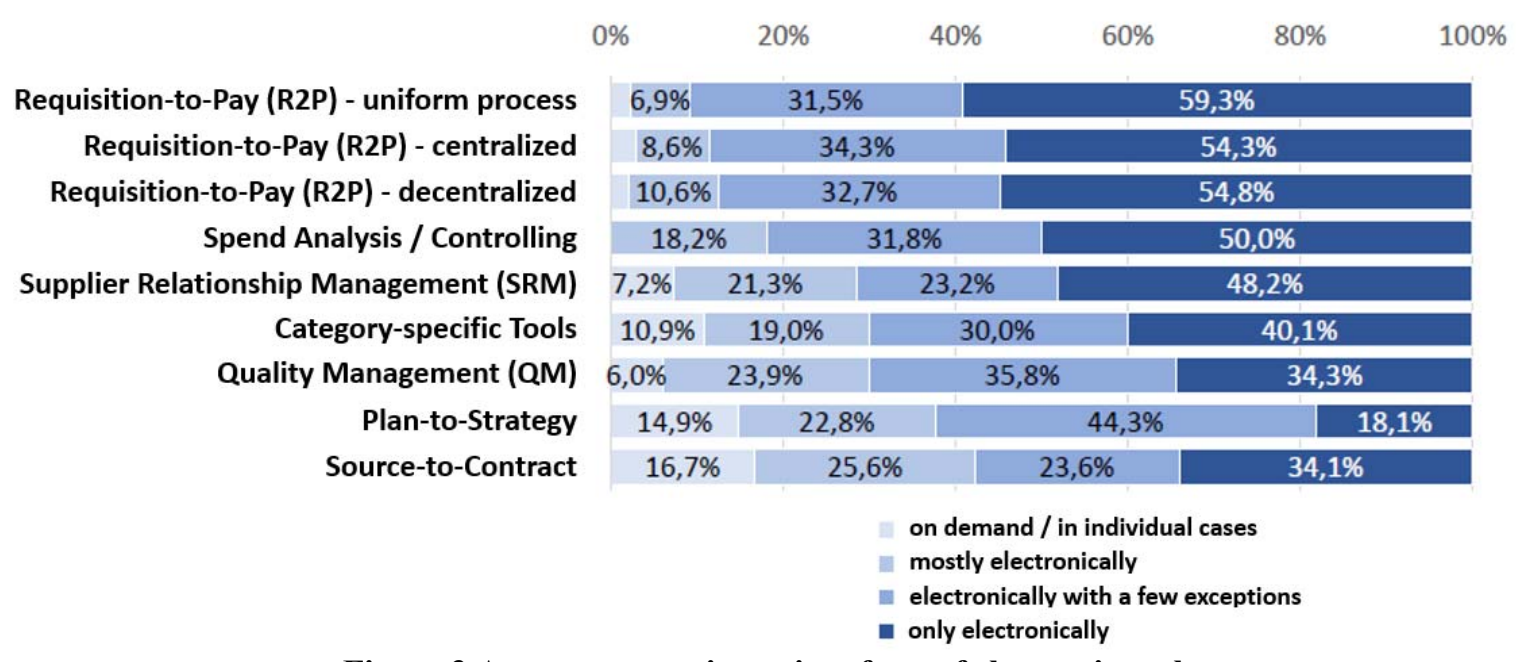

Figure 3 Average target intensity of use of electronic tools (Source: ELEKTRONISCHE BESCHAFFUNG 2020 [1])

From Organization Bundesverband Materialwirtschaft, Einkauf und Logistik e.V. (BME) conducted research points not only to the importance and timeliness of innovation and digitization in the procurement sector, but also offers a transparent and comprehensive view of the level of their implementation and perception within the industry, which accounts for $63 \%$ of survey units. At the same time, it reveals the potential as well as the need for further development in the given area. Research carried out on the market from our side also responds to this need. The main goal was to create an overview about currently available digital solutions in the field of electronic procurement.

\section{Market research - providers and their IT solutions in electronic procurement area}

The main aim of the conducted research was a provision of a transparent overview about available providers and their IT solutions from electronic procurement area. The outcome serves not only scientific purposes but represents also important information for business sector which can benefit greatly of it. Many companies, as also confirmed by research results presented in the previous paragraph, strive for digitalization of their procurement processes.

The research was done in the timeframe from March 2021 till September 2021 and included 90 international companies offering products from electronic procurement environment. The research focus was divided into to parts. First one concentrated on solutions package and second one on international availability, or more precisely its actual international usage.

Following eight categories of electronic tools were investigated:

- Plan-to-Strategy

- Source to Contract

- Requisition-to-Pay (R2P) / Procure-to-Pay2

- Supplier Relationship Management (SRM)

- Spend Analysis / Controlling

- Supplierportal

- Compliance / Sustainability / Risk

- Marketplace 
According to research results there is no company that offers the full range of defined IT solutions. Only 14 companies, which represents $16 \%$, can provide 7 out of 8 categories of electronic tools - all besides of marketplace. Marketplace is available only at 13 companies. Most of the providers offer Requisition-to-Pay (R2P) / Procure-to-Pay2 - 56, and the rarest is the mentioned Marketplace. Highest number of companies, $26 \%$, provide just one electronic solution.

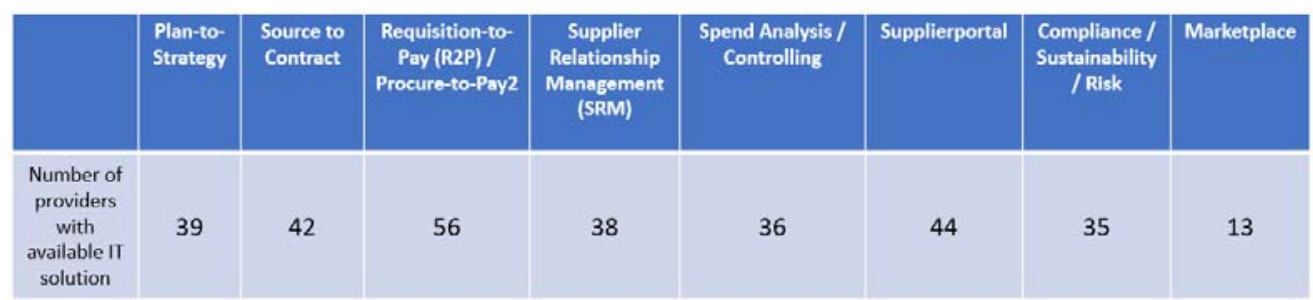

Figure 4 Providers with available IT solution

(Souce: Autors)

\begin{tabular}{|c|c|c|}
\hline & $\begin{array}{l}\text { Availability of } \\
\text { IT solutions }\end{array}$ & $\begin{array}{l}\text { International } \\
\text { availability / } \\
\text { usage }\end{array}$ \\
\hline Number of providers with full range of defined IT solutions & 0 & 0 \\
\hline $\begin{array}{l}\text { Number of providers with } 7 \text { available IT solutions: Plan-to-Strategy, } \\
\text { Source to Contract, Requisition-to-Pay (R2P) / Procure-to-Pay2, Supplier } \\
\text { Relationship Management (SRM), Spend Analysis / Controlling, } \\
\text { Supplierportal, Compliance / Sustainability / Risk }\end{array}$ & 14 & 8 \\
\hline Number of providers with exact 6 available IT solutions & 9 & 3 \\
\hline Number of providers with exact 5 available IT solutions & 6 & 3 \\
\hline Number of providers with exact 4 available IT solutions & 8 & 1 \\
\hline Number of providers with exact 3 available IT solutions & 8 & 3 \\
\hline Number of providers with exact 2 available IT solutions & 7 & 2 \\
\hline Number of providers with exact 1 available IT solution & 23 & 5 \\
\hline Number of providers with no available IT solution from pre-defined ones & 15 & 2 \\
\hline
\end{tabular}

Figure 5 Providers with available IT solution - detailed view

(Source: Autors)

Regarding second research focus we found out that $30 \%$ of IT providers offer their tools and services internationally. Within the survey we realized that only 8 out of them operate with the range of 7 available IT solutions internationally. Similar picture was found out by relatively high number of providers with exact one available IT solution -23 , where only 5 out of it offer their products internationally.

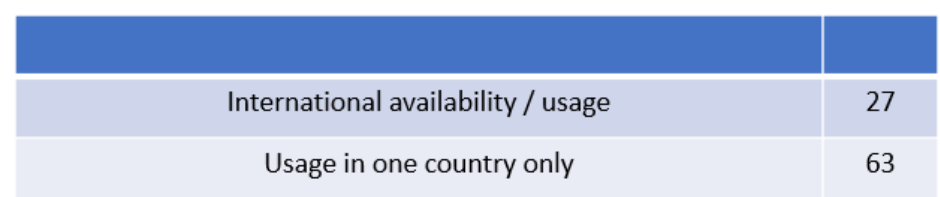

Figure 6 International availability of IT solutions

(Souce: Autors) 


\section{Conclusions}

The conducted survey provided an overview about IT solutions in electronic procurement area and their international availability, or more precisely its actual international usage. We found out that there is now no solution that would cover all pre-defined modules: Plan-to-Strategy, Source to Contract, Requisition-to-Pay (R2P) / Procure-to-Pay2, Supplier Relationship Management (SRM), Spend Analysis / Controlling, Supplierportal, Compliance / Sustainability / Risk and Marketplace. We realized that international availability is also limited and represent just 30\% from the whole pool of IT tools. Based on these facts we assume that to satisfy the target intensity of use of electronic tools it is necessary to reach out for multiple IT providers and combine their eSolutions into one functioning ecosystem.

\section{Literature:}

[1] BOGASCHEWSKI, R., MUELLER, H., BME-BAROMETER, „ELEKTRONISCHE BESCHAFFUNG 2020“, Bundesverband Materialwirtschaft, Einkauf und Logistik / Lehrstuhl für Industriebetriebslehre der Universität Würzburg / HTWK Leipzig, Würzburg, Germany, 2020, 37 p.

[2] KERSTEN W. et al., Digitalisierung als Wegbereiter für effizientere Wertschöpfungsnetzwerke. In Marktorientiertes Produkt- und Produktionsmanagement in digitalen Umwelten, Springer Gabler, Wiesbaden, Germany, 2018, 280 p. ISBN 978-3658-21636-8

[3] KREUTZER, R. et al., Digital Business Leadership: Digitale Transformation Geschäftsmodell-Innovation - agile Organisation - Change-Management, Gabler Verlag, Wiesbaden, Germany, 2017, 310 p. ISBN 978-3-658-11913-3

[4] VAHS, D. - PIETSCHMANN, B., Innovationsmanagement: Von der Produktidee zur erfolgreichen. Schäffer-Poeschel, 2005. 412 p. ISBN 978-3791023557

[5] KLEEMANN, F.C. - GLAS, A.H., Einkauf 4.0: Digitale Transformation der Beschaffung, Springer Gabler, Wiesbaden, Germany, 2017, 49 p. ISBN 978-3-65817228-2

[6] PASSAQUIN, N., Procurement / Innovation. Independently published, 2019, 98 p. ISBN 9781796871654

[7] SCHUPP F., WÖHNER H., Digitalisierung im Einkauf, Springer Gabler, Wiesbaden, Germany, 2018, 171 p., ISBN 978-3-658-16908-4

[8] BME - Bundesverband Materialwirtschaft, Einkauf und Logistik, 2020, [internal source].

\section{Grant support}

The Paper is published with the support of project VEGA 1/0518/19. This research has been further supported by the University of Zilina in the scope of Institutional research $1 / \mathrm{KS} / 2020$ and by Projects KEGA 042/SPU-4/2021 and 052ŽU-4/2021. 